\title{
Gökkuşağı Alabalığı (Oncorhynchus mykiss)'nda Ruşeym İlave Edilen Diyetlerin Viserosomatik İndeks Üzerine Etkileri
}

\author{
Asude Çavuş ${ }^{*}$ \\ ${ }^{1}$ Van Yüzüncü Y11 Üniversitesi, Su Ürünleri Fakültesi, 65000 Van/Türkiye
}

(İlk Geliş Tarihi 17 Aralık 2018 ve Kabul Tarihi 24 Aralık 2018)

(DOI: 10.31590/ejosat.498380)

\section{Özet}

Viserosomatik indeks, balık beslemede büyüme performansının izlenme yöntemlerinden biridir. Bu çalışma, viserosomatik indisler kullanılarak farklı oranlarda ruşeym ilave edilen diyetlerle beslenen gökkuşağı alabalıklarının kondüsyonlarını belirlemek amacıyla yapılmıştır. Kazein-jelatin tabanlı dört deneme diyeti, farklı ruşeym seviyelerini ( $\% 0, \% 5, \% 10$ ve $\% 15)$ içerecek şekilde formüle edilmiştir. Üç tekerrürlü balık grupları (ortalama vücut ağırlığ $10.85 \pm 0.02 \mathrm{~g}$ ) 45 gün boyunca beslenmiştir. Besleme denemesinin sonunda viserosomatik indeks (VSI), balıkların tüm vücut ağırlıkları ve iç organ ağırlıkları baz alınarak analiz edilmiştir. Bu çalışmada VSİ değerleri sırasıyla 11.05 $\pm 1.50,9.99 \pm 1.93,10.01 \pm 1.42$ ve $11.11 \pm 2.10$ olarak hesaplanmıştır. Araştırma sonunda, en yüksek VSİ değeri (11.11) \%15 ruşeym ilave edilen grupta görülürken en düşük VSİ değeri ise (9.99) \%5 ruşeym ilave edilen grupta gözlenmiştir. Sonuçlar, diyetler arasında viserosomatik indeks (VSİ) değerlerinde önemli fark olmadığını göstermiştir $(\mathrm{p}<0.05)$.

Anahtar kelimeler: Gökkuşağı alabalığı; büyüme; ruşeym; VSİ.

\section{Effects of Dietary Wheat Germ on Viscerosomatic Index in Rainbow Trouts (Oncorhynchus mykiss)}

\begin{abstract}
Viscerosomatic index is one of determination methods of growth performance in fish feeding. The present study was carried out to determination the condition of rainbow trout, Oncorhynchus mykiss fed with different dietary wheat germ by using viscerosomatic indices. Four experimental diets based on casein-gelatine were formulated to contain different wheat germ levels $(0 \%, 5 \%, 10 \%$ and $15 \%$ ). Triplicate groups of fish (average body weight $0.85 \pm 0.02 \mathrm{~g}$ ) were fed for 45 days. At the end of the feeding trial the viscerosomatic index (VSI) were analyzed based on total body weight and internal organ weights of the fish. In this study, VSI values were calculated as $11.05 \pm 1.50,9.99 \pm 1.93,10.01 \pm 1.42$ and $11.11 \pm 2.10$, respectively. The highest VSI value (11.11) was found in the group which was fed with $15 \%$ wheat germ supplemented diet, while the lowest VSI value (9.99) was found in the group which was fed with $5 \%$ wheat germ supplemented diet. The results showed no significant differences in the viscerosomatic (VSI) values among the diets $(\mathrm{p}<0.05)$.
\end{abstract}

Keywords: Rainbow trout; growth; wheat germ; VSI.

\section{Giriș}

Sürekli artan kültür balıkçılığı sebebiyle, beslemede balık unu ve balık yağının yetersiz kalacağı tahmin edildiğinden dolayı son zamanlarda alternatif protein kaynağı arayışı başlamıştır [1]. $\mathrm{Bu}$ kaynaklardan birisi de ruşeymdir.

TUİK verilerine göre Türkiye'deki üretimi 2012 y1lında yaklaşık 20.1 milyon ton olan buğdaydan 400 bin ton ruşeym ve bu miktardaki ruşeymden 112 bin ton protein, 40 bin ton yağ, 1.3 milyar kalori enerji elde edilebilir [2,3].
Buğday tanesinde dormant halde bekleyen ruşeym, un sanayinin bir yan ürünüdür. Ruşeymin nişasta oranı düşük; yağ, antioksidan ve protein oranı yüksektir ve pazarlanabilmesi için kurutma, kavurma gibi çeşitli ön işlemler yapılmaktadır [4,5].

Buğday tanesinin \%15'i kepek, \%82'si endosperm, \%3'ü ruşeymden oluşur. Tüm buğday tanesinin içerisindeki proteinin \%8'i, yağın \%20'si külün ise \%10'u ruşeymde yer almaktadır. Aynı zamanda tahıllarda, özellikle buğdayda anti-besleyici faktörler arasında yer alan ruşeym aglutinin, antijenik içerikler, mikotoksin, fitat, fitoöstrojenler, oligosakkaritler, nişastasız

${ }^{1}$ Sorumlu Yazar: Van Yüzüncü Y1l University, Faculty of Fisheries, 65000/Van, a.gultekin@yyu.edu.tr 
polisakkaritler, arabinoksilanlar ve beta-glukanlar sıralanabilir $[6,7]$. Ruşeymde proteaz inhibitörü de bulunmaktadır $[8,9]$.

Çoğu balık türünün iç organlarının ekonomik değeri olmadığı için, viseral organların tüm vücuda olan oranını ifade eden Viserosomatik İndeks (VSI) değerinin olabildiğince düşük olması su ürünleri sektörü açısından tercih edilmektedir [10].

Viserosomatik indeks (VSİ), balıklar tarafından alınan yemlerin viseral organlara olan etkisini belirleyebilmek için hesaplanmaktadır. Yağ oranı fazla yada n-3 PUFA miktarı az olan yemler balıkların iç organlarında yağlanmaya sebep olmakta, bundan dolayı da VSİ değerini yükseltmektedir [11,12].

$\mathrm{Bu}$ çalışmanın amacı, buğdaydan elde edilen ruşeymin gökkuşağ1 alabalığı yemlerinde kontrol grubu (D1) ile karşılaştırılmak üzere, \%5 (D2 grubu), \%10 (D3 grubu) ve \%15 (D4 grubu) oranlarında kullanılarak balıkların viserosomatik indeks (VSİ) değeri üzerine etkilerini araştırmaktır.

\section{Materyal ve Yöntem}

Denemede kullanılan gökkuşağı alabalıkları, Atatürk Üniversitesi Su Ürünleri Fakültesi'nden temin edilmiş ve deneme öncesi adaptasyon süresince bir arada tutulmuştur. Denemenin başlangıcında iyi koşullardaki 420 balık (başlangıç ağırlığ 1 $0.85 \pm 0.02$ g) 12 tanka $(50$ l) 35 'er adet paylaştırılmıştır. Su kalitesi günlük izlenmiştir ve deneme boyunca kabul edilebilir sınırlarda bulunmuştur. Tesadüf parselleri deneme düzenine göre tasarlanan diyet uygulamaları üçer üçer tanklara atanmıştır. İlk iki hafta için balıklar günde dört kere, son dört hafta için ise günde üç kere ağırlıklarının \%3-4'ü kadar yemle beslenmiştir [Çizelge $1,2]$.

Çizelge 1. Farkl seviyelerde ruşeym (\%0, \%5, \%10, \%15) ile hazırlanan araştırma diyetleri.

\begin{tabular}{|c|c|c|c|c|}
\hline & \multicolumn{4}{|c|}{ Diyetler } \\
\hline İçerik (\%) & D1 & D2 & D3 & D4 \\
\hline Kazein (vitaminsiz) & 40.00 & 40.00 & 40.00 & 40.00 \\
\hline Jelatin & 8.00 & 8.00 & 8.00 & 8.00 \\
\hline L-arginine & 0.50 & 0.50 & 0.50 & 0.50 \\
\hline L-methionine & 0.40 & 0.40 & 0.40 & 0.40 \\
\hline L-lysine & 0.80 & 0.80 & 0.80 & 0.80 \\
\hline CPSP $90^{1}$ & 5.00 & 5.00 & 5.00 & 5.00 \\
\hline Dekstrin & 9.10 & 9.10 & 9.10 & 9.10 \\
\hline Buğday unu & 15.00 & 10.00 & 5.00 & 0.00 \\
\hline Ruşeym & 0.00 & 5.00 & 10.00 & 15.00 \\
\hline Balık Yağı & 10.00 & 10.00 & 10.00 & 10.00 \\
\hline Soya Yağ1 & 4.00 & 4.00 & 4.00 & 4.00 \\
\hline Vitamin karışımı ${ }^{2}$ & 2.00 & 2.00 & 2.00 & 2.00 \\
\hline Mineral karışımi ${ }^{3}$ & 3.00 & 3.00 & 3.00 & 3.00 \\
\hline $\mathrm{CMC}$ & 2.00 & 2.00 & 2.00 & 2.00 \\
\hline Stay C-35 & 0.06 & 0.06 & 0.06 & 0.06 \\
\hline Kolin Klorid (\%99) & 0.17 & 0.17 & 0.17 & 0.17 \\
\hline
\end{tabular}

D1: \%0 Ruşeym, D2: \%5 Ruşeym, D3: \%10 Ruşeym, D4: \%15 Ruşeym.

${ }^{1}$ CPSP 90: Balık protein konsatrayonu (\%82-84 ham protein, \%9-13 ham yağ içerir.), Sopropéche S.A., Boulogne-sur-mer, Fransa.

${ }^{2}$ Roche Performance Premix (Hoffman-La Roche, INC., Nutley, N.J., USA), her bir gramında; vitamin A, 2645.50 IU; vitamin D3, 220.46 IU, vitamin E, 44.09 $\mathrm{IU}$; vitamin B-12 $13 \mathrm{mg}$; riboflavin, $13.23 \mathrm{mg}$; niacin, $61.73 \mathrm{mg}$; d-pantothenic asit, $20.05 \mathrm{mg}$; menadione, $1.32 \mathrm{mg}$; folik asit, $1.76 \mathrm{mg}$; tiyamin, $7.95 \mathrm{mg}$ ve ddiyotin, $0.31 \mathrm{mg}$.

${ }^{3}$ Bernhart Tomarelli mineral karıșımı (ICN Pharmaceuticals, Costa Mesa, CA, USA), $100 \mathrm{~g}$ bileşiminde: $2.1 \mathrm{~g}$ kalsiyum karbonat, $73.5 \mathrm{~g}$ kalsiyum fosfat dibazik, $0.227 \mathrm{~g}$ sitrik asit, $0.046 \mathrm{~g}$ bakır sitrat, $0.558 \mathrm{~g}$ demir sitrat, $2.5 \mathrm{~g}$ magnezyum oksit, $0.835 \mathrm{~g}$ magnezyum sitrat, $0.001 \mathrm{~g}$ potasyum iyodür, $8.1 \mathrm{~g}$ potasyum fosfat dibazik, $6.8 \mathrm{~g}$ potasyum oksit, $3.06 \mathrm{~g}$ sodyum klorid, $2.14 \mathrm{~g}$ sodyum fosfat ve $0.133 \mathrm{~g}$ çinko sitrat.
Çizelge 2. Araştırma diyetlerinin besin madde kompozisyonu.

\begin{tabular}{lllll}
\hline & \multicolumn{4}{c}{ Diyetler } \\
\hline İçerik (\%) & D1 & D2 & D3 & D4 \\
\hline Ham protein & 48.40 & 49.93 & 50.27 & 51.20 \\
Ham yağ & 14.46 & 14.91 & 15.36 & 15.81 \\
Kül & 6.26 & 6.25 & 5.96 & 6.25 \\
Nem & $4.31^{\mathrm{c}}$ & $5.08^{\mathrm{b}}$ & $7.85^{\mathrm{a}}$ & $3.16^{\mathrm{d}}$ \\
\hline
\end{tabular}

Yem tüketimleri günlük kaydedilmiştir ve tanklarda dışkı ve yem atıkları günlük sifonlanmıştır, genel temizlik ise haftada bir yapılmıştır. Her iki haftada bir düzenli olarak tanklardaki balıklar tartılmıştır. Altı haftalık besleme çalışmasının sonunda eşitlik 1'e göre VSI'yi hesaplamak için her tanktan 5 adet balık alınıp son vücut ağırlığı ve viseral organ ağırlığı ölçülmüştür [13].

$$
\text { VSİ= } \frac{\text { Tüm iç organ ağırlığı }}{\text { Balık ağırlığı }} \times 100
$$

İstatistik analizlerde, SPSS 18.0 paket programı kullanılarak ANOVA yöntemi analizi yapılmıştır. ANOVA testi sonucunda önemli çıkan grup ortalamaları arasındaki farklılı̆̆ı tespit etmek için, Duncan çoklu karşılaştırma testi kullanılmıştır.

\section{Bulgular ve Tartışma}

Deneme başı canlı ağırlık ortalamaları $0.85 \pm 0.02 \mathrm{~g}$ olan deneme grubu balıklarının deneme süresince (0. gün, 15 . gün, 30 . gün ve 45. gün) ortalama canlı ağırlık değerleri kontrol grubu ve ruşeym verilen gruplar arasında istatistiksel olarak önemli bulunmuştur $(\mathrm{p}<0.05)$. Deneme sonu deneme gruplarında D2 diyeti ile beslenen grup D1, D3 ve D4 ile beslenen gruplara göre daha iyi bireysel büyüme göstermiş ve istatistikî olarak önemli çıkmıştır $(\mathrm{p}<0.05)$.

Farklı seviyelerde ruşeym içeren yemlerle beslenen gökkuşağı alabalığı (Oncorhynchus mykiss) yavrularının deneme sonu oransal büyüme (OB), spesifik büyüme oranı (SBO), yem değerlendirme oranı (YDO), yaşama oranı (YO), hepatosomatik indeks (HSİ) [3] ve viserosomatik indeks (VSİ) değerleri Çizelge 3 'te verilmiştir. Tüm vücut yağ oranı ise D1 için \%7.90, D2 için \%7.03, D3 için \%6.32, D4 için \%4.90 olarak analiz edilmiş, D1 ve D4 arasındaki fark istatistiksel olarak anlamlı bulunmuştur.

Çizelge 3. Araştırma diyetleriyle beslenen balıkların büyüme performanslarını gösteren VSI, $\mathrm{HSI}, \mathrm{OB}, \mathrm{SBO}, \mathrm{YDO}$ ve $\mathrm{YO}$ değerleri [3].

\begin{tabular}{lllll}
\hline & \multicolumn{4}{c}{ Diyetler } \\
\cline { 2 - 5 } & D1 & D2 & D3 & D4 \\
\hline VSİ & $11.05 \pm 1.50$ & $9.99 \pm 1.93$ & $10.01 \pm 1.42$ & $11.11 \pm 2.1$ \\
HSİ & $1.67 \pm 0.28$ & $1.28 \pm 0.24$ & $1.79 \pm 0.39$ & $1.80 \pm 0.14$ \\
OB & $413.2 \pm 56.7^{\mathrm{a}}$ & $459.4 \pm 20.0^{\mathrm{a}}$ & $329.9 \pm 27.1^{\mathrm{b}}$ & $183.5 \pm 3.7^{\mathrm{c}}$ \\
SBO & $3.62 \pm 0.25^{\mathrm{a}}$ & $3.82 \pm 0.08^{\mathrm{a}}$ & $3.24 \pm 0.14^{\mathrm{b}}$ & $2.32 \pm 0.03^{\mathrm{c}}$ \\
YDO & $0.89 \pm 0.07^{\mathrm{a}}$ & $0.81 \pm 0.03^{\mathrm{a}}$ & $1.01 \pm 0.08^{\mathrm{b}}$ & $1.41 \pm 0.04^{\mathrm{c}}$ \\
YO & 98.10 & 95.24 & 93.23 & 97.14 \\
\hline
\end{tabular}

Hazırlanan yemlerle 45 gün boyunca beslenen gökkuşağ1 alabalıkları araştırma sonunda D1'de 4.38 g, D2'de 4.81 g, D3 grubunda $3.67 \mathrm{~g}$ ve D4'de $2.37 \mathrm{~g}$ ağırlığa ulaşmıştır. Büyüme performansları incelendiğinde; D4'ün büyüme oranı ile spesifik büyüme oranı diğer gruplardan önemli derecede düşük çıkarken, VSİ bakımından gruplar arasında fark olmadığı ortaya çıkmıştır ( $p>0.05$ ). En yüksek VSİ değeri D4 yemiyle beslenen grupta en düşük değer ise D2 yemiyle beslenen grupta belirlenmiştir [Şekil 1]. VSİ ve HSİ gruplar bazında paralellik göstermiştir [Çizelge 3]. 


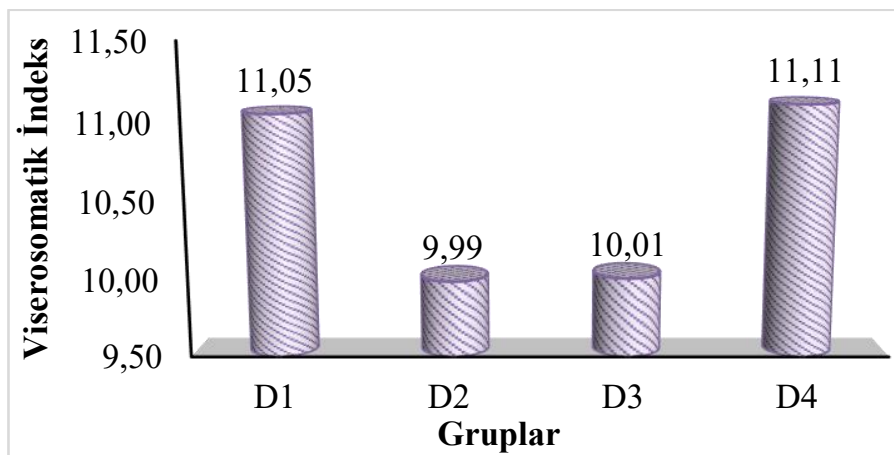

Şekil 1. Farkl seviyelerde ruşeym içeren yemlerle beslenen gökkuşağl alabalı̆̆l (Oncorhynchus mykiss) yavrularının deneme süresince ortalama viserosomatik indeks değerleri.

On hafta boyunca aç bırakılan mersin balıkları zamana bağlı olarak VSİ ve HSİ değerleri önemli ölçüde etkilenmiştir $(\mathrm{p}<0.05)$. Çalışma sonunda oransal olarak iç organ karkastan daha çok ağırlık kaybetmiş̧tir ve bu dokuların lipitleri proteinden daha fazla bir düşüş göstermiştir. Çalışma süresince mersin balıklarının hareket ederken tercih ettiği dokunun iç organ ve tercih ettiği besinin ise lipit olduğu düşünülmüştür [14].

L-karnitinin içeren yemlerle beslenen Labeo rohita fingerlinklerinin HSI değerleri 0.33 ile 0.53 , VSI değerleri ise 11.06 ile 12.23 arasında değişen değerler aldığı belirtilmiştir [15].

Yağ seviyesi yüksek (\%27.5) yemlerle beslenen ortalama 90 g ağırlığındaki gökkuşağı alabalıklarının yaklaşık 11 ayın sonunda, yă̆ seviyesi düşük $(\% 12.6)$ yemlerle beslenen balıklardan VSİ değerleri (\%11.7 ve \%9.1) bakımından daha yüksek çıktığı belirtilmiştir [16]. Bu çalışmada bulunan doğru orantı bizim çalışmamızda görülmemektedir.

Ortalama başlangıç ağırlığı $131.3 \mathrm{~g}$ olan gökkuşağ alabalıkları 58 gün boyunca ticari yemlere farklı oranlarda alfatokoferol asetat $(100,300,500 \mathrm{mg} / \mathrm{kg})$ ilave edilen diyetlerle beslenmiştir. Alfa-tokoferol asetat katkılı yemlerin VSİ ve HSİ değerlerine etki etmediği ancak karaciğer ve filetonun lipit profilini değiştirdiği bildirilmiştir [17]. Bu çalışmada bulunan VSİ değerleri bizim çalışma sonuçlarımız ile örtüşmektedir.

$17 \alpha$-Metiltestosteron içeren yemlerle beslenen gökkuşağ 1 alabalıklarının HSİ değerleri, kas ve iç organlar arası yağlarının oranı incelenmiştir. Yemlerine 17 $\alpha$-Metiltestosteron ilave edilen gökkuşağı alabalıklarının karaciğer ve kaslarındaki yağ oranının artmasına karşın, viseral yağların azaldığı belirtilmiştir [18].

Ortalama başlangıç ağırlığı 104.2 g olan gökkuşağı alabalıkları 90 gün boyunca $\% 40$ ham protein içeren zeolit $(\% 0$ (kontrol), \%2.5, \%5.0 ve \% 10 bentonit veya mordenit) katk1l diyetlerle beslenmiştir. Bentonit ve mordenit katkılı yemlerin VSİ ve HSİ değerlerini düşürdüğü bildirilmiştir. En az VSİ ve HSİ değerine sahip olan \% 10'luk mordenit içeren yemlerle beslenen grup, \% 5 mordenit denemesi dişında tüm deneme gruplarından önemli ölçüde farklı çıktığı bildirilmiştir [19]. Bu çalışmada bulunan sonuçlar ile mevcut çalışma sonuçları arasında paralellik yoktur.

Farklı oranlarda ulva ve spirulina ilave edilen diyetlerle ( $\% 5$ ulva, $\% 10$ ulva, $\% 5$ spirulina, $\% 10$ spirulina ve kontrol grubu- $\% 0$ alg) 12 hafta boyunca beslenen gökkuşağı alabalıkları daha sonra 3 haftalık açlığa tabi tutulmuşlardır. Aç bırakıldığ vücut ağırlığı, VSİ, HSİ ve karkasın kimyasal kompozisyonu analiz edilmiştir. Alg içeren yemlerle beslenen balıklar arasında ağırlık kaybı açısından önemli bir fark bulunmazken, kontrol grubuna göre \%50 daha az ağırlık kaybetmişlerdir. Protein miktarı tüm gruplarda sabit iken toplam lipit miktarı her grupta önemli ölçüde azalmıştır. Balıkların düşük seviyede alg içeren yemlerle beslenmesi ağırlık kaybını azalttığı için ekonomik açıdan avantaj sağladığı bildirilmiştir [20].

Farklı oranlarda kanola yağ 1 içeren yemlerle beslenen gökkuşağı alabalıklarının HSİ değerleri 0.80 ile 1.04 , VSİ değerleri ise 10.03 ile 11.99 arasında değişen değerler aldığı belirtilmiştir [21]. Bu çalışmada bulunan VSİ değerleri bizim çalışma sonuçlarımız ile benzerlik göstermektedir.

Farklı oranlarda buğday nişastası ilave edilen $(\% 20, \% 26$, $\% 33, \% 40$ ve $\% 47$ ) protein oran $1 \% 23.5$ ve yağ oran1 $\% 5.7$ olan yemlerle 8 hafta boyunca beslenen ortalama $6.9 \mathrm{~g}$ ağırlığındaki ot sazanlarının (Ctenopharyngodon idella) VSİ ve HSİ değerleri değerlendirilmiştir. Ot sazanlarının normal büyümeleri için en fazla \%33 buğday nişastası içeren yemlerle beslenmeleri gerektiğini, oranın artmasıyla alınan fazla karbonhidratın yağa dönüşerek çeşitli dokularda biriktiği, dolayısıyla VSİ değerinin de $\operatorname{arttığı~belirtilmiştir~[22].~Benzer~sonuçlar~bizim~çalışmamızda~da~}$ görülmektedir.

Ortalama ağırlıkları 115.97 g olan gökkuşağı alabalıklarının bir kısmı 8 gün boyunca aç bırakılmış, diğer kısmı ise günde iki kere beslenmiş ve VSİ değerleri arasında istatistiki açıdan fark olmadığı $(\mathrm{p}>0.05)$ belirtilmiştir [23].

Farklı oranlarda $(\% 0, \% 20, \% 25, \% 30$ ve $\% 35)$ maltoz içeren yemlerle 90 gün boyunca beslenen ortalama $2.1 \mathrm{~g}$ ağırlığındaki nil tilapyalarının VSİ değerlerinde önemli bir farklılık görülmezken, HSİ değerlerinde ise kontrol grubuyla \%30 ve \%35 maltoz içeren gruplar arasındaki farklılık önemli bulunmuştur [24]. Yine bu çalışma sonuçları da VSİ açısından bizim çalışma sonuçlarımız ile örtüşmektedir.

Balık yağı yerine farklı oranlarda ( $\% 50$ soya yağ $1, \% 100$ soya yağı, \%100 palmiye yağı, \%100 balık yağı) bitkisel yağların ikame edildiği yemlerle 12 hafta boyunca beslenen ortalama 245.29 g ağırlığındaki Larmichthys crocea türü deniz balıklarının VSİ değerleri incelnmiştir. Ventral kasların ve iç organların yağ içerikleri \%100 balık yağı bulunan yemlerle beslenen balıklarda diğer gruplardan önemli ölçüde düşük çıkmıştır $(P<0.05)$. Diyet grupları arasında VSİ, HSİ, kondüsyon faktörü bakımından önemli bir farklılık bulunmamıştır $(P>0.05)$ [25]. Bu çalışmada bulunan sonuçlar bizim çalışma sonuçlarımız ile örtüşmektedir.

Balık unu yerine farklı oranlarda $(\% 0, \% 35, \% 50)$ fermente soya unu katkılı yemlerle 94 gün boyunca beslenen gökkuşağ1 alabalıklarının VSİ değerleri arasında önemli bir fark bulunmamıştır [26]. Bu çalışmada bulunan sonuçlar bizim çalışma sonuçlarımız ile benzerdir.

Farklı oranlarda $(\% 0, \% 2.5, \% 5, \% 10$ ve $\% 20)$ Spirulina platensis ile ikame edilen ticari yemlerle 16 hafta boyunca beslenen Trichopodus trichopterus türü guramilerin VSİ değerleri değerlendirilmiştir. $\% 5$ ve $\% 10$ oranında $S$. platensis içeren yemlerle beslenen balıkların VSİ değerleri arasındaki fark istastistiki olarak önemli bulunmuştur [27]. Bu çalışmada bulunan sonuçlar mevcut çalışma ile uyumlu değildir.

Farklı oranlarda $(\% 0.00, \% 0.01, \% 0.05, \% 0.10$ ve $\% 0.20)$ borik asit içeren yemlerle 120 gün boyunca beslenen ortalama $17.89 \mathrm{~g}$ ağırlığındaki gökkuşağı alabalıklarının VSİ ve HSI değerleri incelenmiştir. Sirasıyla HSI değerleri 1.238, $1.251,1.292,1.325$ ve 1.387 ; VSI değerleri ise $17.149,16.63$, $16.322,15.041$ ve 13.965 olarak bulunmuştur. Yemlerine borik asit ilave edilen gökkuşağı alabalıklarının karaciğerlerinin büyüdüğü iç organlarının ise nispeten ağırlık kaybettiği sonucuna varılmıştır [10]. Bu çalışmada bulunan sonuçlar, çalışma sonuçlarımız ile paralellik göstermemektedir. 
Aynı su kaynağında bulunan 3 farklı işletme tarafından farklı yemlerle beslenen gökkuşağı alabalıklarının VSİ değerleri \% $11.64, \% 16.10$ ve $\% 13.31$ olarak bulunmuş ve istatistiki açıdan fark olduğu $(\mathrm{p}<0.05)$ bildirilmiştir [28].

Farklı oranlarda $\left(\% 00, \%_{0} 1, \% 02, \% 03\right.$ ve $\left.\% 44\right)$ mannan oligosakkarit içeren yemlerle 15 hafta boyunca beslenen çipuraların VSİ değerleri sırasıyla 6.59, 6.45, 6.58, 6.31ve 6.32 olarak bulunmuştur. Gruplar arasında VSİ değerlerinde önemli bir farklılık görülmemiştir [29]. Bu çalışmada bulunan VSİ sonuçları bizim çalışma sonuçlarımız ile benzerdir.

VSİ üzerine yapılan çalışmalarda, orta seviyede yağlı ve/veya düşük proteinli yemlerle beslenen balıkların VSİ değerlerinin daha düşük olduğu belirlenmiştir. Çok yağlı ve düşük n-3 PUFA oranına sahip balık yemleri, VSİ ve HSİ değerlerini yükselttiği ve karaciğerin yağlanmasına neden olduğu bildirilmiştir [11].

Çalışmamızda VSİ değerleri istatistiksel olarak bir fark oluşturmamıştır. Bu çalışmada olduğu gibi balık yemlerine ilave edilen keten tohumu yağı, alfa-tokoferol asetat, maltoz, soya yağı, palmiye yağı, fermente soya unu, kanola küspesi, kolza tohumu yağı, keten tohumu yağının VSİ değerini etkilemediğini; farklı ticari yemler, enginar yaprağı özü, zeolit, spirulina ve buğday nişastasının VSİ değerini etkilediği yapılan çalışmalarda belirtilmiştir [17, 19, 22, 24, 25, 26, 27, 30, , 31, 32, 33, 34].

Değişik ruşeym seviyeleri, balıkların karaciğer ağırlığını etkilememiştir. Atay ve ark. (1979) alabalıkları farklı protein ve enerji seviyelerindeki yemlerle beslemişler, HSİ değerleri arasında farklılık bulmamışlardır [14]. Bransden ve ark. (2003) Atlantik salmonlarının rasyonlarına balık yağı yerine ayçiçeği yağı katmışlardır, HSİ değerleri açısından bizim çalışmamız ile benzerlik göstermektedir [36]. Ancak yaptığımız çalışmanın aksine Beyter (2008), Adelizi ve ark. (1998), Gümüş (2003) yaptıkları çalışmalarda HSİ değerleri istatistiki olarak farklı bulunmuştur [33, 37, 38].

\section{Sonuç}

Viserosomatik indeks üzerine yapılan bu çalışmada, yavru gökkuşağı alabalıklarının diyetlerinde ilave edilen farklı ruşeym seviyeleri, VSİ oranlarını etkilememiştir. Gökkuşağı alabalıklarının ağırlık kazancında önemli artışlar gözlenmiştir $(\mathrm{p}<0.05)$. Bu artışlar özellikle D2 (\%5 ruşeym) grubunda dikkate değerdir. Ancak \%10'dan daha fazla ruşeym ilavesinin canlı ağırlık artışını olumsuz etkilediği saptanmıştır (Çizelge 3). Ruşeym bitkisel bir protein kaynağı olduğu için, canlı ağırlık artışını yavaşlattığ 1 düşünülmektedir.

Deneme boyunca grupların yem tüketimleri birbirinden farklı bulunmuştur. $\mathrm{Bu}$ durumda ruşeymin, gökkuşağı alabalığı yemlerinde lezzeti ve balıkların iştahını etkilediği düşünülebilir. Yemleme esnasında yemlere karşı ilginin en az olduğu grup D4 grubu idi. Bu durum büyümedeki gerilemeyi açıklayabilir.

Sonuç itibariyle, besleme çalışmalarında belli bir seviyeye kadar ruşeym kullanımının uygun olduğu, ancak bir seviyeden sonra ruşeymin büyümeyi olumsuz etkilediği söylenebilir.

Kazein-jelatin tabanlı yemlere $\% 5$ ruşeym ilave edilmesi balıkların büyümesini ve yem değerlendirme oranını olumlu yönde etkilemiştir. Sonuç olarak balık unu üreten fabrikalar ruşeymi kullanmalıdır.

D2 grubunun en yüksek oransal büyüme ve spesifik büyüme oranına sahip olmasının yanında, en düşük VSİ ve HSİ değerine sahip olması; aldığı yemlerin kasları büyüterek karkas verimini yükselttiği sonucuna varılabilir. Gökkuşağı alabalığı yemlerine
$\% 5$ oranında ruşeym ilave edilmesinin insanlar tarafindan tüketilmeyen iç organların oranını azalttığı; üretici ve tüketiciler için ekonomik açıdan faydalı olduğu düşünülmektedir.

\section{Kaynaklar}

[1] Bayır, M., (2011). Fraklı yă̆ kaynaklarının kahverengi alabalık (Salmo trutta)'ta büyüme ve yă asidi kompozisyonuna etkileri ile antioksidan enzim aktiviteleri vasıtasıyla açlığa cevaplarının ölçülmesi. Atatürk üniv. Su ürünleri ABD. Doktora tezi.

[2] Anonim, (2012). http://sgb.tarim.gov.tr/tarim_politikalari/ opd/cilt3_.pdf .01.11.2012.

[3] Gültekin, A., (2013). Diyetlere Farklı Oranlarda İlave Edilen Ruşeymin (Buğday Embriyosunun) Gökkuşağı Alabalığı (Oncorhynchus mykiss) Yavrularının Performansı ve Kimyasal Bileşimi Üzerine Etkileri. Yüksek lisans tezi, Fen Bilimleri Enstitüsü, Atatürk Üniversitesi.

[4] Melikoğlu, M., (2005). Buğday rüşeyminden lipit ve antioksidanların ultrasondestekli özütlenmesi. Kimya müh. Yüksek lisans tezi.

[5] Akkaya, A., (1994). Buğday Yetiştiriciliği. Kahramanmaraş Sütçü İmam Üniv. Ziraat Fak., Kahramanmaraş Sütçü İmam Üniv. Genel Yayın No:1, Ziraat Fak. Genel Yayın No:1, Ders Kitaplar1 Yayın No:1, s 34,208.

[6] Elgün, A., Ertugay, Z., (2000). Tahıl İşleme Teknolojisi. Atatürk Üniv. Ziraat Fak., Yayın No:297, (4. Bask1, Erzurum,s 481).

[7] Doğan, G., Bircan, R., (2009). Bitkisel yem hammadelerinde bulunan antibesleyici faktörler ve balıklar üzerine etkileri. Journal of FisheriesSciences.com 3(4): 323- 332.

[8] Pal, G.P., Betzel, C.B., Jany, K.D., Saenger, W. (1986). Crystallization of the bifunctional proteinase/amylase inhibitor or PKI-3 and its complex with proteinase K. FEBS Lett;197:111-4.

[9] Sharma, A., Gupta M.N. (2001). Three phase partitioning as a large-scale separation method for purification of a wheat germ bifunctional protease/amylase inhibitor Process Biochemistry, 37; 193-196.

[10]Öz, M., Dikel, S., İnanan B. E., Karaşahin, T., Durmuş, M., Uçar, Y. 2017. Borik Asidin Gökkuşağı Alabalığı (Oncorhynchus mykiss)'nın Hepatosomatik ve Viserosomatik İndeks Değerleri Üzerine Etkileri. JAVST, 2(1), 6-10.

[11]Cheng Chang A., Chen Yung C.., Liou Hwa C., Chang Fing. C. (2005). Effect of Dietary Protein and Lipids on Blood Parameters and Superoxide Anion Production in the Grouper, Epinephelus coioides (Serranidae: Epinephalinae), Pg. 2- 23, Depertmant of Aquaculture, National Taiwan Ocean University, Keelung, Taiwan.

[12]Korkut, A. Y., Kop, A., Demirtaş, N., Cihaner, A. (2007). Balık beslemede gelişim performansının izlenme yöntemleri. Ege Üniversitesi Su Ürünleri Dergisi, 24(1-2), 201-205.

[13]Company, R., Calduch-Gıner, J.A., Kaushık, S.J., Perezsanchez, J. (1999). Growth performance and adiposity in gilthead sea bream (Sparus aurata): risks and benefits of high energy diets. Aquaculture, 171: 279- 292.

[14]Hung, S. S., Liu, W., Li, H., Storebakken, T., Cui, Y. (1997). Effect of starvation on some morphological and biochemical parameters in white sturgeon, Acipenser transmontanus. Aquaculture, 151(1-4), 357-363.

[15]Keshavanath, P., Renuka, P. (1998). Effect of dietary Lcarnitine supplements on growth and body composition of fingerling rohu, Labeorohita (Hamilton). Aquaculture Nutrition, 4(2), 83-8. 
[16]Jobling, M., Koskela, J., Savolainen, R. (1998). Influence of dietary fat level and increased adiposity on growth and fat deposition in rainbow trout, Oncorhynchus mykiss (Walbaum). Aquaculture Research, 29(8), 601-607.

[17]Yildiz, M. (2004). The study of fillet quality and the growth performance of rainbow trout (Oncorhynchus mykiss) fed with diets containing different amounts of vitamin E. Turkish Journal of Fisheries and Aquatic Sciences, 4(2).

[18]Güzel, Ş., Güllü, K. (2006). 17 $\alpha$-Metiltestosteron'un Gökkuşağı Alabalığının (Oncorhynchus mykiss, W., 1792) Kimyasal kompozisyonu, Fileto Verimi, Viseral Yağ ve Hepatosomatik İndeks Üzerine Etkisi. EU Journal of Fisheries Aquatic Sciences, 23, 233-36.

[19]Eya, J. C., Parsons, A., Haile, I., Jagidi, P. (2008). Effects of dietary zeolites (bentonite and mordenite) on the performance juvenile rainbow trout Onchorhynchus mykiss. Australian Journal of Basic and Applied Sciences, 2(4), 961-967.

[20] Güroy, D., Güroy, B., Merrifield, D. L., Ergün, S., Tekinay, A. A., Yiğit, M. (2011). Effect of dietary Ulva and Spirulina on weight loss and body composition of rainbow trout, Oncorhynchus mykiss (Walbaum), during a starvation period. Journal of animal physiology and animal nutrition, 95(3), 320-327.

[21]Dernekbaş1, S. (2012). Digestibility and liver fatty acid composition of rainbow trout (Oncorhynchus mykiss) fed by graded levels of canola oil. Turkish Journal of Fisheries and Aquatic Sciences, 12(1), 105-13.

[22]Tian, L. X., Liu, Y. J., Yang, H. J., Liang, G. Y., Niu, J. (2012). Effects of different dietary wheat starch levels on growth, feed efficiency and digestibility in grass carp (Ctenopharyngodon idella). Aquaculture international, 20(2), 283-293.

[23]Baki, B., Kaya D., Öztürk, R. (2013). Gökkuşağ1 Alabalığında (Oncorhynchus mykiss Walbaum, 1792) Süreli Açlı̆̆ın Biyokimyasal Kompozisyonuna Etkisi. Biyoloji Bilimleri Araştırma Dergisi 6 (1): 49-53.

[24]Ighwela, K. A., Ahmad, A. B., Abol-Munafi, A. B. (2014). The selection of viscerosomatic and hepatosomatic indices for the measurement and analysis of Oreochromis niloticus condition fed with varying dietary maltose levels. International Journal of Fauna and Biological Studies, 1(3), 18-20.

[25]Duan, Q., Mai, K., Shentu, J., Ai, Q., Zhong, H., Jiang, Y., Guo, S. (2014). Replacement of dietary fish oil with vegetable oils improves the growth and flesh quality of large yellow croaker (Larmichthys crocea). Journal of Ocean University of China, 13(3), 445-452.

[26]Barnes, M. E., Brown, M. L., Neiger, R. (2015). Comparative performance of two rainbow trout strains fed fermented soybean meal. Aquaculture international, 23(5), 1227-1238.

[27]Khanzadeh, M., Fereidouni, A. E., Berenjestanaki, S. S. (2016). Effects of partial replacement of fish meal with Spirulina platensis meal in practical diets on growth, survival, body composition, and reproductive performance of threespot gourami (Trichopodus trichopterus)(Pallas, 1770). Aquaculture international, 24(1), 69-84.

[28]Dernekbaşı, S., Hamzoğlu, G. (2018). Farklı İşletmelerde Yetiştirilen Gökkuşağı Alabalığının (Oncorhynchus mykiss) Vücut ve Yağ Asit Profilleri. Menba Su Ürünleri Fakültesi Dergisi, 4(1), 1-7.

[29]Gelibolu, S., Yanar, Y., Genc, M. A., Genc, E. (2018). The Effect of Mannan-Oligosaccharide (MOS) as a Feed Supplement on Growth and Some Blood Parameters of Gilthead Sea Bream (Sparus aurata). Turkish Journal of
Fisheries and Aquatic Sciences 18: 817-823. DOI: 10.4194/1303-2712-v18_6_08.

[30]Menoyo, D., Lopez-bote, C.J., Obach, A., Bautista, J.M. (2005). Effects of dietary fish oil sustitution with linseed oil on the performance, tissue fatty nacis profile, metabolism, and oxidative stability of Atlantic salmon, Journal of Animal Science, 83: 2853-2862.

[31]Aybal N. Ö. (2007). Tilapia (Oreochromis niloticus L.) Yavrularının Yemlerinde Protein Kaynağı Olarak Kanola (Brassica spp.) Küspesi Kullanma Olanakları. Doktora tezi, Fen Bilimleri Enstitüsü, Süleyman Demirel Üniversitesi.

[32]Leaver, M.J., Villeneuve,A.N.L., Obach, A., Jensen, L., Bron, J.E., Tocher, D.R and Taggart, J.B. (2008). Functional genomics reveals increases in cholesterol biosynthetic genes and highly unsaturated fatty acid biosynthesis after dietary substitution of fish oil with vegetable oils in Atlantic salmon (Salmo salar). BMC Genomics, 9:299.

[33]Beyter, N., (2008). Farklı Ticari Yemlerle Beslenen Gökkuşağı Alabalıklarının (Oncorhynchus mykiss) Büyüme Performansına, Balık Eti Bileşimine ve Yağ asitleri Profiline Etkisi. Ankara Üni. Gıda Müh. Anabilim Dalı. Doktora tezi.

[34]Atıc1, A. A. (2012). Farkl1 Oranlarda Enginar (Cynara scolymus L.) Yaprağı Özü Kullanılan Yemlerle Beslenen Levrek (Dicentrarchus labrax L.)'lerin Büyüme Performansı ve Kimyasal Kompozisyonlarının Belirlenmesi. Yüksek Lisans Tezi. Çukurova Üniv. Fen Bil.Enst. SuÜrünleri Yetiştiricilik Anabilim Dalı.

[35]Atay vd. (1979) Atay, D., Erdem, M., Erer, H. (1979). Alabalık rasyonlarında değişik protein ve enerji düzeylerinin balıkların kimyasal ve histolojik yapılarına etkileri. TÜBİTAK, VHAG-OKBA, 1.

[36]Bransden M. P., Carter C.G., Nichols P. D. (2003). Replacement of fish oil with sunflower oil in feeds for Atlantic salmon (Salmo salar L.): effect on growth performance, tissue fatty acid composition and disease resistance. Comparative Biochemistry and Physiology, Part B 135, 611-625.

[37]Adelizi, P. D., Rosati, R.R., Werner, K., Wu, Y. V., Muench T.R., White, M.R., Brown P.B. (1998). Evaluation of fish-meal free diets for rainbow trout, Oncorhynchus mykiss. Aquaculture Nutrition 4; 255-262.

[38]Gümüş, E. (2003). Karbonhidrat ve yağ düzeyleri farklı rasyonların gökkuşağı alabalığı (Oncorhynchus mykiss Walbaum, 1792)'nın büyümesi ve bazı kimyasal bileşenleri üzerine etkisi. Süleyman Demirel Üniversitesi Fen Bilimleri Enstitüsü, Su Ürünleri Temel Bilimleri Anabilim Dalı. Doktora tezi. 